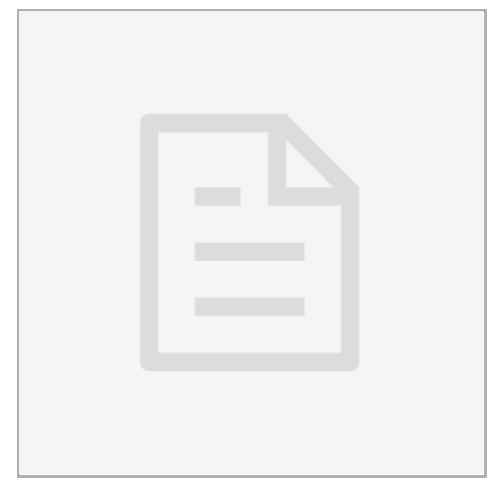

AUG 28, 2018

\section{open 2 Access}

\section{DOI:}

dx.doi.org/10.17504/protocol s.io.s25egg6

\section{Protocol Citation: Pat} Martinez 2018. Protoplast method for Chromosome prep with Zymoseptoria tritici. protocols.io

https://dx.doi.org/10.17504/p rotocols.io.s25egg6

\section{License: This is an open} access protocol distributed under the terms of the Creative Commons Attribution License, which permits unrestricted use, distribution, and reproduction in any medium, provided the original author and source are credited

\section{Protocol status: Working}

Created: Aug 28, 2018

Last Modified: Aug 28, 2018

\section{PROTOCOL integer ID:} 15165

\section{(3) Protoplast method for Chromosome prep with Zymoseptoria tritici}

\author{
Pat Martinez ${ }^{1}$ \\ ${ }^{1}$ Bruce McDonald lab \\ Zymoseptoria community protocols (STBnet)
}

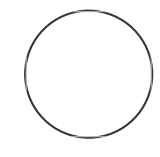

Petteri Karisto

\section{ABSTRACT}

Preparation of Zymoseptoria tritici isolates for extraction of chromosomes via pulsed-field electrophoresis

Pat Martinez 1990 (Bruce McDonald lab) (Simplified from Cooley, et al, Curr. Genet. 13:383-389.)

\title{
Prepare spores
}

1 Grow single-spore isolate in $40 \mathrm{ml}$ yeast-sucrose broth, without chloramphenicol, until cells are in log phase, ( 5-8 days at room temperature) in shaker at 150-200 rpm. Do not grow cells past 
log phase! In stationary phase, protoplasts do not form as easily.

Transfer culture to sterile $50 \mathrm{ml}$ Falcon tube. Harvest spores and mycelium by centrifuging at top speed in IEC clinical centrifuge for 5 minutes. Pour off supernatant.

\section{Make protoplasts}

2 Add $40 \mathrm{ml}$ of $600 \mathrm{mM} \mathrm{MgSO} 4 \mathrm{pH} 5.8$ (sterile) and resuspend cells completely in solution. Harvest washed cells by centrifuging at top speed for 5 minutes in IEC clinical centrifuge.

3 Resuspend pellet in $20 \mathrm{ml}$ of a $1.2 \mathrm{M} \mathrm{MgSO} 4 \mathrm{pH} 5.8$ solution containing $3.0 \mathrm{mg} / \mathrm{ml}$ of Novozyme 234 (this solution must be filter sterilized, mix Novozyme with $1.2 \mathrm{M}$ sltn and vortex to mix before filter sterilizing). Sterilize by forcing solution slowly through $5 \mathrm{ml}$ syringe-mounted Nalgene filter. Transfer spore-Novozyme solution to a $40 \mathrm{ml}$ glass Corex centrifuge tube.

Incubate at $30^{\circ} \mathrm{C}$ for 2 hours without agitation. Check for formation of protoplasts after two hours, and again at 15 minute intervals. Do not agitate tube any more than necessary!

\section{Harvest protoplasts}

5 Once protoplasts have formed, centrifuge in IEC clinical at top speed for 3 minutes. Should find that the majority of pinkish cells are floating on top of liquid; these are protoplasts and some undigested spores. Pipette away cloudy, brown liquid underneath protoplast layer and save top layer.

6 To wash cells, add $20 \mathrm{ml}$ of $1.2 \mathrm{M}$ sorbitol and resuspend cells. Harvest cells by spinning at top speed, IEC clinical for 5 minutes. Discard supernatent and save pellet of protoplasts. Repeat this wash step again (two washes total). After second wash, resuspend protoplasts in $0.4 \mathrm{ml}$ of 1.0 $\mathrm{M}$ sorbitol and quantify protoplast concentration with hemocytometer (probably will need to make 1:10 dilution of protoplast prep). Add 1.2 M sorbitol to achieve protoplast concentration of between $5-10 \times 10^{8}$ protoplasts per $\mathrm{ml}$.

7 Add equal volume of $\mathbf{2 . 2 \%}$ low melting point (LMP) agarose (in TE) to protoplasts and mix well but gently. Keep solution liquid in $37^{\circ} \mathrm{C}$ water bath. Tape closed one end of plug molds to receive protoplast solution. Use pasteur pipette to pipette protoplast-LMP solution into each well of plug mold (push pipette end to bottom of well and work upward as protoplast solution enters well) and allow to solidify for two hours at $4^{\circ} \mathrm{C}$. 
8 Push out plugs with flame-blunted pasteur pipette into a $15 \mathrm{ml}$ Falcon tube containing $10 \mathrm{ml}$ lysis buffer ( $1 \%$ sarkosyl, $450 \mathrm{mM}$ EDTA, $1 \mathrm{mg} / \mathrm{ml}$ proteinase $\mathrm{K}$ ). Incubate tubes at $50^{\circ} \mathrm{C}$ for 48 hours, replacing lysis buffer once after 24 hours.

9 Rinse plugs in $500 \mathrm{mM}$ EDTA and store in $500 \mathrm{mM}$ EDTA at $4^{\circ} \mathrm{C}$ 